\title{
TANTANGAN TERHADAP PANCASILA SEBAGAI IDEOLOGI DAN DASAR NEGARA PASCA REFORMASI
}

\author{
Husein Muslimin \\ Fakultas Hukum Universitas Merdeka Malang \\ Jl. Terusan Raya Dieng No. 62-64 Malang \\ husein.muslimin@unmer.ac.id
}

\begin{abstract}
Pancasila is a basic value from Indonesia as a nation, it is also a basic ground in nation and country life since Indonesia independence. Regarding how important the existence of Pancasila, it is must be going through a long and hard process to create Pancasila. This paper will highlight and study Pancasila creation as an ideology and country basic ground. This paper will also study about Pancasila position after reformation time and how those ideology impelemented in challenging changes in after reformation.
\end{abstract}

Keywords: Pancasila, Ideology, Reformation.

\begin{abstract}
ABSTRAK
Pancasila merupakan nilai dasar dari bangsa Indonesia, serta merupakan landasan dalam kehidupan berbangsa dan bernegara di Indonesia sejak kemerdekaan. Mengingat pentingnya keberadaan Pancasila tersebut di Indonesia, tentunya pembuatan ideologi Pancasila telah melewati proses yang sangat panjang. Tulisan ini akan menyoroti dan mengkaji sejarah pembuatan Pancasila dan kedudukannya sebagai ideologi dan dasar negara. Tulisan ini juga akan menyoroti kedudukan Pancasila pasca reformasi dan bagaimana ideologi dan dasar negara tersebut diterapkan dalam menghadapi tantangan perubahan di masa reformasi.
\end{abstract}

Kata Kunci: Ideologi, Pancasila, Reformasi.

Pancasila berisi nilai-nilai dan cita-cita yang digali dari bumi Indonesia sendiri, artinya digali dan diambil dari kekayaan, rohani, moral dan budaya masyarakat dan bangsa Indonesia. Di sini Pancasila dikenal sebagai Ideologi terbuka dalam arti bahwa Pancasila sebagai Ideologi yang mampu mengikuti perkembangan jaman serta dinamis, merupakan sistem pemikiran terbuka dan merupakan hasil konsensus masyarakat itu sendiri, oleh karena itulah Pancasila juga merupakan dasar negara yang sudah barang tentu harus terwujud dalam segala aspek kehidupan berbangsa dan bernegara.
Pancasila merupakan konsensus politik yang sangat menakjubkan, para pendiri negara mampu menampung semua kepentingan yang ada kedalam ideologi Pancasila, dan yang luar biasa adalah mengambil jalan tengah antara dua pilihan ekstrim yakni negara sekuler dan negara agama. Dasar negara yang telah ditetapkan itu merupakan pilihan yang sesuai dengan karakter bangsa, asli, yang akhirnya menjadi negara yang berkarakter religius.

Betapa hebatnya para pendiri republik ini, betapa tidak, mereka telah memberi landasan yang kokoh bagi suatu bangsa besar yang multiethnik, 
multi agama, ribuan pulau, dan kaya sumberdaya alam (yang menjadi daya tarik asing untuk campur tangan). Pancasila adalah titik pertemuan atau nukthatul liqo yang lahir dari suatu kesadaran bersama pada saat krisis. Kesadaran tersebut muncul dari kesediaan untuk berkorban demi kepentingan yang lebih besar membentuk bangsa yang besar. Pancasila adalah suatu konsensus dasar yang menjadi syarat utama terwujudnya bangsa yang demokratis (As'ad Said Ali: 2009).

Rumusan Pancasila yang kita kenal sekarang ini bukanlah sesuatu yang tiba-tiba apalagi kebetulan, akan tetapi dari hasil pemikiran yang mendalam dan tidak terlepas dari persiapan kemerdekaan yang dilakukan oleh BPUPKI, dalam sidang pertamanya pada tanggal 29 Mei sampai dengan 1 Juni 1945 membahas rumusan dasar negara. Dengan demikian jelas bahwa BPUPKI dalam sidang pertama tersebut membahas untuk menentukan dasar negara yang pada akhirnya ditetapkanlah Pancasila, jadi Pancasila adalah jelas foundasi negara bukan yang lain, bukan sekedar pilar tetapi merupakan dasar bangunan yang menentukan bentuk dan wujud bangunan itu sendiri. Hal ini juga tampakjelas dari pidato Ketua BPUPKI Dr Kanjeng Raden Tumenggung Radjiman Wedyodiningrat pada pembukaan sidangdengan mengajukan pertanyaan kepada anggota yakni "Apa dasar Negara Indonesia yang akan kita bentuk ini "?

Mencari jawaban inilah kemudian beberapa tokoh menyampaikan gagasannya dalam sidang tersebut yakni antara lain:

Moh. Yamin dalam pidatonya pada tanggal 29 Mei 1945 mengemukakan 5 (lima) dasar negara Indonesia yakni:

- Peri Kebangsaan;

- Peri Kemanusiaan;

- Peri Ke-Tuhanan;

- Peri Kerakyatan;

- Kesejahteraan Rakyat.

Namun pada akhir pidatonya Moh, Yamin secara tertulis menyampaikan gagsannya tersebut yang rumusan kalimatnya agak berbeda sebagai berikut:

1. Ke-Tuhanan Yang Maha Esa;

2. Kebangsaan Persatuan Indonesia;

3. Rasa Kemanusiaan Yang Adil dan Beradab;

4. Kerakyatan yang dipimpin oleh hikmat kebijaksanaan dalam Permusyawaratan Perwakilan;

5. Keadilan sosial bagi seluruh Indonesia.

Tanggal 31 Mei 1945 Prof. Dr. Supomo mengusulkan dasar negara sebagai berikut:

- Persatuan;

- Kekeluargaan;

- Keseimbangan lahir dan batin;

- Musyawarah;

- Keadilan rakyat.

Ir. Soekarno dalam pidatonya pada tanggal 1 Juni 1945 menyampaikan lima hal yang menjadi dasar negara merdeka, yaitu:

- Kebangsaan Indonesia;

- Internasionalisme atau kemanusiaan;

- Mufakat atu demokrasi;

- Kesejahyeraan sosial;

- Ke - Tuhanan yang berkebudayaan.

Pendapat dari tiga tokoh tersebut kemudian dibahas oleh panitia sembilan pada tanggal 22 Juli 1945 yang pada akhirnya menghasilkan rumusan yang memberikan gambaran tentang maksud dan tujuan dibentuknya negara Indonesia Merdeka yang terkenal dengan sebutan Piagam Jakarta atau Jakarta Charter.

Tanggal 10 - 17 Juli BPUPKI mengadakan sidang kedua, dalam sidang kedua ini BPUPKI menerima laporan dari Panitia Sembilan tentang isi Piagam Jakarta, serta membahas Rancangan Pembukaan Undang Undang Dasar 1945, sekaligus pada saat itu tugas BPUPKI dianggap selesai dan dibubarkan.

Tugas mempersiapkan kemerdekaan Indonesia kemudian diserahkan kepada Panitia Per- 


\section{Jurnal Cakrawala Hukum \\ Vol.7, No.1 Juli 2016: 30-38}

siapan Kemerdekaan Indonesia (PPKI) yang dibentuk pada tanggal 7 Agustus 1945. Pada tanggal 18 Agustus setelah terjadi perdebatan yang sangat berat akhirnya dicapai kesepakatan dengan merubah Piagam Jakarta menjadi Pembukaan UUD 1945 dengan rumusan Pancasila sebagai berikut:

- Ke - Tuhanan Yang Maha Esa;

- Kemanusiaan yang adil dan beradab;

- Persatuan Indonesia;

- Kerakyatan yang dipimpin oleh hikmat kebijaksanaan dalam permusyawaratan perwakilan;

- Keadilan sosial bagi seluruh rakyat Indonesia.

Pancasila sebagai Ideologi dan dasar Negara ini tidak akan diganti dan diubah selama Negara Kesatuan Reublik Indonesia masih ada. Sebagaimana disampaikan oleh Ketua Mahkanah Konstitusi Arief Hidayat yang menyatakan Pancasila tidak dapat diubah karena merupakan kristalisasi dari jiwa bangsa Indonesia yang memiliki sifat religius, kekeluargaan, gotong royong, dan toleran. (https:/ / news.detik com/berita/d-3573010/ ketuamk-pancasila-tidak-bisa-diubah).

Namun disisi lain di era reformasi Pancasila dipersoalkan oleh sejumlah anak bangsa. Saat terjadi krisis yang mengakibatkan keterpurukan di hampir semua bidang kehidupan, Pancasila dijadikan kambing hitam. Menurut mereka hanya liberalisme dan kapitalisme yang terbukti memenangkan pertarungan ideologi dunia bisa menyelamatkan Indonesia. Bahkan, ada salah seorang tokoh yang terang-terangan menyatakan diri " $A k u$ seorang neoliberalis". Sementera yang lain berani mengatakan, "tinggalkan Pancasila, ikutlah neolib" (As'ad Said Ali: 2009).

Upaya untuk menyisihkan Pancasila masih terus berlanjut, Hizbut Tahrir Indonesia (HTI) harus dibubarkan dengan surat keputusan Menteri Hukum dan Hak Asasi Manusia Nomor AHU30.AH.0108 Tahun 2017, sebagai pelaksanaan dari Peraturan Pemerintah Pengganti Undang Undang Nomor 2 Tahun 2017 tentang Organisasi
Kemasyarakatan. HTI dinilai aktivitasnya banyak yang bertentangan dengan Ideologi Pancasila dan Negara Kesatuan Republik Indonesia (Kompas, 2017).

Dengan kenyataan ini Pemerintah harus lebih waspada terhadap organisasi kemasyarakatan maupun perorangan yang melakukan aktivitas-aktivitas yang secara langsung maupun tidak langsung dapat merongrong kewibawaan Pancasila. Demikian pula penanaman terhadap nilai-nilai Pancasila terhadap Bangsa Indonesia harus dimulai sejak dini dan melalui segala bidang.

\section{Menempatkan Pancasila di Era Pasca Reformasi}

Hakekatnya fungsi Pancasila tidak berubah dan bahkan tidak boleh berubah, yakni tetap sebagaimana digagas secara cerdas oleh pendiri negara pada saat itu, yaitu sebagai dasar negara, sebagai ideologi nagara, maupun sebagai pandangan hidup bangsa. Akan tetapi Pancasila sebagai Ideologi terbuka harus mampu menyesuaikan perkembangan masyarakat yang terus melaju dalam perubahan, ini artinya bahwa Pancasila perlu dikaji secara ilmiah dalam rangka aktualisasi.

Sebagai dasar sekaligus ideologi negara, maka Pancsila bagi bangsa Indonesia sudah tidak bisa ditawar. Ditegaskan oleh M. Mahfud MD. bahwa Pancasila yang telah diumumkan di dalam Pembukaan Undang Dasar 1945 adalah modus vivendi (kesepakatan luhur) bangsa indonesia. Pancasila sangat cocok dengan realitas bangsa Indonesia dengan berbagai kepentingan yang semula mungkin saling bertentangan secara diametral (Anis Ibrahim, 2010).

\section{Pancasila Sebagai Ideologi}

Kata 'idea' berasal dari kata bahasa Yunani 'eidos' yang artinya 'bentuk'. Disamping itu masih diketemukan katalain yakni 'idein' yang berarti 'melihat'. Dengan demikian secara harafiah ideologi 
berarti ilmu pengetahuan tentang ide-ide, atau ajaran tentang pengertian-pengertian dasar. Dalam pengertian sehari-hari, 'idea' disamakan dengan cita-cita, yakni cita-cita yang bersifat tetap, yang harus dicapai, sehingga cita-cita yang bersifat tetap itu sekaligus merupakan dasar, pandangan atau faham (Kaelan, 2016, 111).

Menurut Notonagoro ideologi negara sebagai cita-cita negara, atau cita-cita yang menjadi basis bagi suatu teori atau sistem kenegaraan untuk seluruh rakyat dan bangsa yang bersangkutan yang pada hakeketnya merupakan asas kerokhanian yang antara lain memiliki ciri sebagai berikut:

a. Mempunyai derajat yang tertinggi sebagai nilai hidup kebangsaan dan kenegaraan;

b. Oleh karena itu mewujudkan suatu asas kerokhanian, pandangan dunia, pandangan hidup, pedoman hidup, pegangan hidup yang dipelihara, dikembangkan, diamalkan, dilestarikan kepada generasi berikutnya, diperjuangkan dan dipertahankan dengan kesediaan berkorban (Kaelan, 2016, 113).

Pancasila sebagai ideologi bangsa dan negara Indonesia bukanlah hasil dari olah fikir perseorangan yang kemudian dinobatkan menjadi sebuah ideologi. Soekarno mengatakan bahwa Pancasila digali dari bumi pertiwi, dan bumi Indonesia sendiri, artinya bahwa Pancasila berisi nilainilai, moral dan budaya bangsa Indonesia yang sudah ada sejak bangsa Indonesia ada dan bukan ideologi yang dipaksakan dari luar. Nilai-nilai itupun tidak serta merta diberlakukan begitu saja, tetapi melalui sebuah proses panjang yang terbuka dan demokratis yang pada akhirnya perbedaanperbedaan yang ada dapat dikompromikan dalam sebuah kesepakatan bersama. Ini berarti sebagai ideologi, Pancasila tidak bersifat tertutup melainkan menempatkan diri sebagai ideologi terbuka.

Ideologi terbuka tidak hanya dapat dibenarkan, melainkan dibutuhkan. Oleh karena itu ideologi terbuka adalah milik seluruh rakyat, sehingga masyarakat dapat menemukan dirinya, kepribadiannya di dalam ideologi tersebut. Ideologi terbuka ini berisi nilai-nilai dasar, dalam teori stuffen dari Hans Kelsen berada pada posisi yang tertinggi sehingga isinya tidak operasional. Nilai-nilai itu baru dapat dioperasionalkan ketika sudah dijabarkan dalam keputusan-keputusan yang sudah diberi bentuk berupa konstitusi atau peraturan perundang-undangan yang lainnya.

Ideologi Pancasila yang bersifat aktual, dinamis, antisipatif, dan senantiasa mampu menyesuaikan dengan perkembangan zaman. Sebagai ideologi terbuka maka Pancasila memiliki dimensi sebagai berikut:

a. Dimensi idealis, yaitu nilai-nilai dasar yang terkandung dalam Pancasila yang bersifat sistematis dan rasional yaitu hakikat nilai-nilai yang terkandung dalam lima sila: ketuhanan, kemanusiaan, persatuan, kerakyatan dan keadilan, maka dimensi idealis Pancasila bersumber pada nilai-nilai filosofis yaitu filsafat Pancasila. Oleh karena itu dalam setiap ideologi bersumber dari pandangan hidup nilainilai filosofis (Poespowardoyo dalam Kaelan, 2016, 116);

b. Dimensi normatif, nilai-nilai yang terkandung dalam Pancasila perlu dijabarkan dalam suatu sistem norma, sebagaimana terkandung dalam Pembukaan UUD NKRI 1945 yang memiliki kedudukan tertinggi dalam tertib hukum Indonesia. Dalam pengertian ini maka Pembukaan yang di dalamnya memuat Pancasila dalam alinea IV, berkedudukan sebagai 'staat sfundamental norm', agar ideologi mampu dijabarkan ke dalam langkah operasioanal perlu memiliki norma yang jelas (Poespowardoyo dalam Kaelan, 2016, 117).

c. Dimensi realistis, suatu ideologi harus mampu mencermnkan realitas yang hidup dan berkembang dalam masyarakat oleh karena itu Pancasila selain memiliki dimensi nilai-nilai ideal normatif, maka Pancasila harus dijabar- 
kan dalam kehidupan nyata sehari-hari baik dalam kaitannya bermasyarakat maupun dalam segala aspek penyelenggaraan negara. Dengan demikian Pancasila sebagai ideologi terbuka tidak bersifat 'utopis' yang hanya berisi ideide yang mengawang, namun bersifat realistis artinya mampu dijabarkan dalam kehidupan yang nyata dalam berbagai bidang (Kaelan, 2016, 117).

Tiga dimensi tersebut tidak terpisah satu sama lain, tetapi merupakan satu kesatuan yang tidak terpisahkan, artinya Pancasila tidak hanya merupakan sistem ide-ide belaka yang jauh dari kenyataan hidup sehari-hari, Pancasia juga bukan hanya merupakan doktrin yang bersifat normatif, dan juga bukan hanya bersifat pragmatis yang hanya menekankan segi praktis dan realistis belakatanpa idealisme yang rasional, ideologi Pancasila yang bersifat terbuka pada dasarnya berisi nilai-nilai dasar sila-sila Pancasila yang bersifat tetap, yang kemudian dijabarkan dan dilaksanakan secara dinamis, terbuka dan senantiasa mengikuti perkembangan jaman. Pancasila juga senantiasa terbuka terhadp pengaruh budaya asing, akan tetapi nilai-nilai dasar yang ada di dalamnya bersifat tetap. Dengan kata lain bahwa Pancasila bisa menerima pengaruh budaya asing dengan prinsip substansi Pancasila yakni, ketuhanan, kemanusiaan, persatuan, kerakyatan serta keadilan sosial bersifat tetap.

\section{Pancasila Sebagai Dasar Negara}

Sebagai dasar negara Republik Indonesia Pancasila dicantumkan dalam alinea IV Pembukaan UUD NKRI 1945 yang bunyinya sebagai berikut: '.............maka disusunlah Kemerdekaan Kebangsaan Indonesia itu dalam suatu Undang Undang Dasar Negara Indonesia yang yang terbentuk dalam suatu susunan Negara Republik Indonesia yang berkedaulatan rakyat dengan berdasar kepada Ketuhanan Yang Maha
Esa, Kemanusiaan yang adil dan beradap, Persatuan Indonesia dan Kerakyatan yang dipimpin oleh hikmat kebijaksaan dalam Permusyawaratan/Perwakilan, serta dengan mewujudkan suatu Keadilan sosial bagi seluruh rakyat Indonesia". Anak kalimat yang berbunyi '......... dengan berdasarkan kepada....... dst' sebagaimana tersebut diatas mengandung dua makna yakni pertama hal tersebut secara yuridis memiliki makna sebagai dasar negara; kedua, walaupun sampai pada kalimat terakhir alinea IV tersebut tidak diketemukan kata 'Pancasila' secara eksplisit, anak kalimat'......... dengan berdasarkan kepada.......dst' ini memiliki makna dasar negara adalah Pancasila. Hal ini didasarkan pada interpretasi secara historis, sebagaimana yang dilakukan BPUPKI dalam sidangnya yang pertama ketua BPUPKI Kanjeng Raden Tumenggung Radjiman Wedyodiningrat mengajak anggota untuk menentukan dasar negara dengan melemparkan pertanyaan 'apa dasar negara Indonesia yang akan kita bentuk ini ' beberapa tokoh menyampaikan gagasannya yang kemudian terjadi pembahasan dan perdebatan yang sangat sengit, namun pada akhirnya disepakati dasar negara Indonesia adalah Pancasila yang isinya seperti yang dicantumkan dalam alinea IV Pembukaan UUDNRI 1945.

Pancasila sebagai dasar negara pada hakekatnya adalah sumber dari segala sumber hukum atau sumber tertib hukum. Hal ini mengandung konsekuensi yuridis, yaitu bahwa seluruh peraturan perundang-undangan Republik Indonesia harus sejiwa dan sejalan dengan Pancasila. Dengan kata lain, isi dan tujuan peraturan perundangundangan RI tidak boleh menyimpang dari jiwa Pancasila.

Pokok-pokok fikiran yang terdapat dalam Pembukaan UUDNRI 1945 yang di dalamnya ada dasar negara Pancasila yang sudah barang tentu menjadi dasar bagi penyelenggaraan negara, terdapat sembilan prinsip pokok yang mendasari penyusunan sistem penyelenggaraan Negara Indonesia dalam rumusan undang-undang di masa depan yaitu (Jimly Asshiddiqie, 2005, 66): 
1. Prinsip Ketuhanan Yang Maha Esa Sesuai dengan pengertian sila pertama Pancasila sebagaimana termaktup dalam Pembukaan UUDNRI 1945, setiap manusia Indonesia sebagai rakyat dan Warga Negara Indonesia, diakui sebagai insan beragama berdasarkan Ketuhanan yang Maha Esa. Paham Ketuhanan Yang Maha Esa tersebut merupakan pandangan dasar dan bersifat primer yang secara substansial menjiwai keseluruhan wawasan kenegaraan bangsa Indonesia. Kehidupan bernegara, prinsip Ketuhanan Yang Maha Esa diwujudkan dalam paham Kedaulatan rakyat dan sekaligus dalam kedaulatan hukum yang saling berkaitan satu sama lain. Keduanya diwujudkan dalam pelembagaan sistem demokrasi yang berdasar atas hukum dan prinsip negara hukum yang demokratis. Hal ini melahirkan persamaan kedudukan warga negara dihadapan hukum, kedaulatannya disalurkan melalui parlemen, dan materi konstitusi serta peraturan perundang-undangan tidak boleh bertentangan dengan nilai-nilai Ketuhanan yang Maha Esa;

2. Sejak proklamasi kemerdekaan 17 Agustus 1945, bentuk pemerintahan yang dipilih adalah Republik dan bukan kerajaan. UUDNRI 1945 dengan tegas menyatakan bahwa Indonesia adalah negara hukum. Didalamnya terkandung pengertian dan pengakuan terhadap prinsip supremasi hukum dan konstitusi, dianutnya prinsip pemisahan dan pembatasan kekuasaan, adanya jaminan-jaminan hak asasi manusia, peradilan yang bebas dan tidak memihak, dalam paham negara hukum itu, hukumlah yang memegang komando tertinggi dalam penyelenggaraan negara;

3. Paham Kedaulatan Rakyat dan Demokrasi Negara Indonesia juga menganut paham kedaulatan rakyat. Pemilik kekuasaan tertinggi yang sesungguhnya dalam negara Indonesia adalah rakyat. Kekuasaan itu harus disadari berasal dari rakyat, oleh rakyat, dan untuk rakyat;
4. Demokrasi Langsung dan Demokrasi Perwakilan Kedaulatan rakyat Indonesia diselenggarakan secara langsung dan melalui sistem perwakilan. Secara langsung, kedaulatan rakyat itu diwujudkan dalam tiga cabang kekuasaan yang tercermin dalam Majelis Permusyawaratan Rakyat yang terdiri dari Dewan Perwakilan Rakyat dan Dewan Perwakilan Daerah sebagai pemegang kewenangan legislatif; Presiden dan Wakil Presiden sebagai pemegang kekuasaan eksekutif dan Mahkamah Agung serta Mahkamah Konstitusi sebagai pelaksana kekuasaan kehakiman;

5. Pemisahan Kekuasaan dan Prinsip Checks and Balance

UUDNRI 1945 pasca amandemen, kedaulatan rakyat itu ditentukan dibagikan secara horizontal dengan cara memisahkan menjadi kekuasaan-kekuasaan yang dinisbatkan sebagai fungsi lembaga-lembaga negara yang sederajat dan saling mengendalikan satu sama lain berdasarkan prinsip checks and balence, kekuasaan legislatif berada pada Majelis Permusyawaratan Rakyat, tetapi Majelis ini terdiri dari dua lembaga perwakilan yang sederajat dengan lembaga negara lainnya. Kekuasaan eksekutif oleh Presiden dan Wakil Presiden, sedangkan kekuasaan kehakiman dilakukan oleh dua jenis mahkamah yaitu Mahkamah Agung dan Mahkamah Konstittusi;

6. Sistem Pemerintahan Presidensiil

Berdasarkan UUDNRI 1945 pemerintahannya menganut sistem Presidensiil, yang pada pokoknya adalah sebagai berikut:

Pertama, dalam sistem pemerintahan presidensil ini, Presiden dan Wakil Presiden merupakan satu institusi penyelenggara kekuasaan eksekutif negara yang tertinggi dibawah Undang Undang Dasar.

Kedua, presiden dan Wakil Presiden dipilih oleh rakyat secara langsung, karena itu secara politik tidak bertanggung jawab kepada Majelis Permusyawaratan Rakyat atau parlemen, 
melainkan bertanggung jawab langsung kepada rakyat yang memilihnya.

Ketiga, Dewan Perwakilan Rakyat dapat meminta pertanggung jawaban hukum apabila Presiden diduga melakukan pelanggaran hukum, dan diproses sesuai dengan ketentuan dalam Undang Undang Dasar.

Keempat, dalam hal terjadi kekosongan jabatan Presiden atau Wakil Presiden, pengisiannya dapat dilakukan melalui pemilihan dalam sidang Majelis Permusyawaratan Rakyat.

Kelima, para Menteri adalah pembantu Presiden, diangkat dan diberhentikan oleh Presiden, bertanggung jawab kepada Presiden dan tidak kepada parlemen.

Keenam, untuk membatasi kekuasaan Presiden, ditentukan bahwa masa jabatan Presiden adalah 5 (lima) tahun dan tidak boleh lebih dari dua kali masa jabatan;

7. Persatuan dan Keragaman

Dengan adanya tingkat keragaman yang sangat tinggi dalam bidang suku bangsa, agama, dan budaya yang diwarisi bangsa Indonesia, mengharuskan bangsa Indonesia dengan seerat-eratnya dalam keragaman tersebut;

8. Paham Demokrasi Ekonomi dan Ekonomi

Pasar Sosial

Paham kedaulatan rakyat di Indonesia, selain berkenaan dengan demokrasi politik, juga mencakup paham demokrasi ekonomi. Sistem perwakilan politik diwjudkan melalui lembaga Dewan Perwakilan Rakyat, sedangkan sistem perwakilan fungsional diwujudkan melalui DewanPerwakilan Daerah yang berorientasi teritorial dan kedaerahan. Dengan demikian perwakilan golongan atau pelaku ekonomi dan golongan-golongan rakyat lainnya di luar sistem kepartaian dapat disalurkan aspirasinya melalui lembaga perwakilan daerah. Dalam paham demokrasi sosial, negara berfungsi sebagai alat kesejahteraan, artinya negara ini bukan kapitalis dan liberalis, sehingga negara ber- tanggung jawab terhadan kesejahteraan seluruh rakyatnya.

9. Cita Masyarakat Madani

Di akhir abad XX, gelombang liberalisme baru berkembang dimana-mana, dan bersamaan dengan itu terjadi kegagalan paham sosialisme lama diberbagai penjuru dunia. Sehubungan dengan hal tersebut, keberdayaan masyarakat madani atau civil society dalam hubungan antara negara, masyarakat dan pasar berkembang sangat pesat disertai oleh gelombang globalisasi yang mempengarui perikehidupan seluruh umat manusia. Pengertian-pengertian mengenai masyarakat madani yang perlu ditingkatkan pemberdayaannya, haruslah menjadi perhatian bagi setiap penyelenggara negara.

\section{Dinamika Masyarakat Indonesia Pasca Reformasi}

Tahun 2007, Universitas Islam Negeri Jakarta melalui lembaganya yakni Pusat Pengkajian Islam dan Masyarakat (PPIM) melakukan survei yang hasilnya menunjukkan bahwa mayoritas responden $(84,7 \%)$ lebih mendukung Negara Kesatuan Republik Indonesia dan Pancasila ketimbang berapirasi negara Islam (22,8\%). Sebelumnya Lingkaran Survei Indonesia (LSI) pada 2006 melakukan survei yang hasilnya 69,6 persen responden masih mengidealkan sistem kenegaraan berdasarkan Pancasila, 11,5 persen menginginkan seperti negara Islam, dan hanya 3,5 persen menginginkan Indonesia seperti negara demokrasi Barat (As;ad SaidAli, 2009, 1). Hasil ini cukup menggembirakan sebab responden yang menganggap Pancasila sebagai sistem kenegaraan yang terbaik atau diidealkan menunjukkan angka yang sangat signifikan, ini artinya ideologi Pancasila masih tetap tertancap di masyarakat Indonesia.

Akan tetapi persoalan ideologi ini masih tetap ada dan memerlukan perhatian bersama. Survei yang dilakukan oleh Harian Kompas 1 Juni 
2008 memberikan hasil yang memperlihatkan pengetahuan masyarakat mengenai Pancasila merosot tajam, 48,4 persen responden berusia 1729 tahun tidak bisa menyebutkan sila-sila Pancasila secara lengkap dan benar, 42,7 persen responden berusia 30-45 tahun salah menyebut sila-sila Pancasila, dan responden 46 tahun keatas lebih parah yakni, sebanyak 60,6 persen salah menyebut sila-sila Pancasila (As'ad Said Ali, 2009, 2).

Hasil-hasil survei tersebut tentu sangat memprihatinkan, penerimaan yang tinggi terhadap Pancasila seperti tergambar dari hasil survei yang dilakukan oleh UIN Jakarta maupun oleh LSI ternyata tidak dibarengi dengan pengetahuan yang baik terhadap Pancasila itu sendiri.

Sebagaimana disebutkan dimuka pada era reformasi Pancasila dipersoalkan dan dijadikan kambing hitam dari berbagai keterpurukan yang dialami oleh bangsa ini. Pancasila yang seharusnya sebagai nilai, dasar moral etik bagi negara dan aparat pelaksana negara, dalam kenyataannya digunakn sebagai alat legitimasi politik. Puncak dari keadaan tersebut ditandai dengan hancurnya ekonomi nasional, maka timbullah berbagai gerakan masyarakat sebagai gerakan moral politik yang menuntut adanya reformasi disegala bidang politik, ekonomi dan hukum (Syahrial Syarbaini, 2014, 143).

Dengan adanya orde baru tumbang, mengakibatkan fobia terhadap Pancasila. Dasar negara yang semula banyak dikagumi itu, untuk sementara waktu seolah dilupakan karena hampir selalu identik dengan rezim orde baru. Seolah-olah dikesampingkannya Pancasila ini, awalnya memang tidak nampak suatu dampak negatif yang berarti, namun semakin hari dampaknya makin terasa dan berdampak sangat fatal terhadap kehidupan berbangsa dan bernegara. Dalam kehidupan sosial, masyarakat kehilangan kendali atas dirinya, akibatnya terjadi konflik-konflik horisontal dan vertikal secara masif yang pada akhirnya melemahkan sendi-sendi persatuan dan kesatuan bangsa dan negara Indonesia. Bidang budaya, kesadaran masyarakat atas keluhuran budaya bangsa Indonesia mulai luntur, yang pada akhirnya terjadi disorientasi kepribadian bangsa yang diikuti dengan rusaknya moral generasi muda (Syahrial Syarbaini, 20014, 143).

Kondisi tersebut menjadikan prihatin berbagai kalangan termasuk para cendekiawan maupun pejabat negara yang peduli akan hal tersebut. Sekitar tahun 2004 Azyumardi Azra menggagas rejuvenasi Pancasila sebagai faktor integratif dan salah satu fundamen identitas nasional. Seruan tersebut tampak signifikan karena proses amandemen UUDNRI 1945 sempat memunculkan Piagam Jakarta. Indonesia juga dilanda gerakan terorisme mengatas namakan agama. Tidak lama kemudian muncul gejala Perda Syariah disejumlah daerah. Rangkaian gejala tersebut seakan melengkapi kegelisahan publik selama reformasi yang mempertanyakan arah gerakan reformasi dan demokratisasi. Seruan Azyumardi direspon sejumlah kalangan. Diskursus tentang Pancasila kembali menghangat dan meluas usai Simposium Peringatan Hari Lahir Pancasila yang diselenggarakan FISIP - UI pada 31 Mei 2006 (As'ad Said Ali, 2009, 52).

Tataran implementasi, jelas masih jauh dari harapan, carut marutnya politik, ekonomi, anjloknya moral generasi muda, maraknya peyalahgunaan obat terlarang, korupsi yang tiada henti, menunjukkan bahwa nilai-nilai Pancasila tidak menyentuh mental spiritual, energi Pancasila tidak bergerak pada ranah ini.

Penyelenggara negara, penegak hukum, dan elit politik banyak terbukti melakukan korupsi. Maka sebelumnya, mereka harus menjadi sasaran pembumian Pancasila sampai kesanubari, apalagi jika sudah terbukti korupsi (Kompas, 2017). Akan tetapi untuk jangka panjang sasaran pendidikan Pancasila melalui jalur pendidikan masih sangat diperlukan. Walaupun tetap menimbulkan tanda tanya, tetapi kiranya itu yang menjadimaksud Presiden Joko Widodo membentuk Unit Kerja 
Presiden Pembinaan Ideologi Pancasila (UKP PIP). Peraturan Pemerintah Pengganti Undang Undang Nomor 2 Tahun 2017 tentang Organisasi Kemasyarakatan, juga merupakan upaya pemerintah untuk menangkal secara yuridis terhadap organisasi yang akan mengikis nilai-nilai Pancasila.

Sebagai dasar negara, ideologi bangsa dan negara, perekat bangsa, Pancasila harus selalu dipertahankan dan ditanamkan kepada seluruh rakyat Indonesia. Disampaikan oleh Jimly Asshiddiqie, memang sejak reformasi banyak orang terutama generasi muda yang salah sangka mengenai relevansi Pancasila dimasa kini apalagi mendatang. Anggapan demikian jelas keliru, yang banyak dikeluhkan orang dari masa lalu adalah tindakan penyalahgunaan Pancasila itu untuk kepentingan kekuasaan, bukan eksistensi Pancasila itu sendiri sebagai falsafah hidup dan cermin impian bersama seluruh anak bangsa tentang hidup berbangsa dan bernegara yang kita idealkan bersama (Yudi Latif, 2011).

Rektor UGM Panut Mulyono dalam konggres Pancasila IX di UGM 22 Juli 2017: Pancasila adalah living ideologi yang hidup dan dipraktikkan dalam pemerintahan dan kehidupan bermasyarakat. "kami sadar dan faham dalam dinamika global memberikan tantangan kepada Pancasila. Oleh karena itu kami berusaha memahami tantangan itu dan mengatasi dengan baik dan efektif"'(kompas.com, 2017).

\section{Penutup}

Pancasila adalah jelas pondasi negara bukan yang lain bukan sekedar pilar tetapi merupakan dasar bangunan yang menentukan bentuk dan wujud bagunan itu sendiri. Pancasila sebagai ideologi dan dasar negara ini tidak akan diganti dan diubah selama Negara Kesatuan Republik Indonesia masih ada. Hakekatnya fungsi pancasila tidak berubah dan bahkan tidak boleh berubah, yakni tetap sebagaimana yang digagas secara cerdas oleh pendiri negara saat itu, yaitu sebagai dasar negara, sebagai ideologi negara, maupun sebagai pandengan hidup bangsa.

Pancasila digali dari bumi pertiwi berarti pancasila berasal nilai moral dan budaya Bangsa Indonesia yang sudah ada sejak Bangsa Inonesia ada dan bukan ideologi yang dipaksakan dari luar. Pancasila tidak bersifat tertutup melainkan ideologi terbuka, artinya didak hanya dapat membenarkan melainkan dibutuhkan, oleh karena itu ideologi terbuka milik seluruh rakyat sehingga masyarakat dapat menemukan dirinya, kepribadiaanya didalam ideologi tersebut. Ideologi pancasila bersifat aktual, dinamis dan senantiasa mampu menyesuaikan perkembangan zaman.

Pancasila sebagai dasar negara pada hakekatnya adalah sumber dari segala sumber hukum atau sumber tertib hukum. Sebagai dasar negara, ideologi bangsa, dan negara, perekat bangsa, pancasila harus selalu dipertahankan dan ditanamkan kepada seluruh rakyat Indonesia. Pancasila sebagai benteng dan pegangan dalam kehidupan bangsa dan bernegara saat ini dan dimasa akan datang.

\section{Daftar Pustaka}

Asshidiqie, Jimly, 2005, Konstitusi dan Konstitusionalisme Indonesia, Konstitusi Press, Jakarta.

Ali, As'ad Said, 2009. Negara Pancasila, Jalan Kemaslahatan Berbangsa, Penerbit Pustaka LP3ES Indonesia, Jakarta.

Budiyono, Kabul, 2010, Pendidikan Pancasila untuk Perguruan Tinggi, Penerbit Alfabeta, Bandung, 2016, Mukthie, Konstitusionalisme Demokrasi, Penerbit In-Trans Publising, Malang.

Kaelan, 2016, Pendidikan Pancasila, Penerbit Paradigma, Yogyakarta.

Latif, 2011, Yudi, Negara Paripurna, Historitas, Rasionalitas, dan Aktualitas Pancasila, Penerbit PT Gramedia Pustaka Utama, Jakarta.

Syarbani, Syahrial, 2016, Pendidikan Pancasila di Perguruan Tinggi (Implementasi Nilai-Nilai Karakter Bangsa), Penerbit Ghalia Indonesia, Bogor, 